\title{
Supporting Evidence, Potential Adverse Effects, and known Drug Interactions of the Complementary Alternative Medicines which are Frequently used by Prostate Cancer Patients
}

\author{
Harmeet Deol ${ }^{1}$, Alan Truong ${ }^{2}$, Tibebe Woldemariam ${ }^{3}$, Xiaodong Feng ${ }^{3}$ and Ruth Vinall ${ }^{*}$ \\ ${ }^{1}$ PGY1 Resident, Corpus Christi Medical Center, USA \\ 2Pharmacy student, California Northstate University College of Pharmacy (CNUCOP), Elk Grove, USA \\ ${ }^{3}$ Associate Professor, California Northstate University College of Pharmacy (CNUCOP), Elk Grove, USA
}

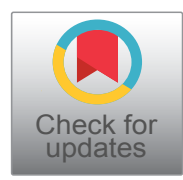

*Corresponding author: Ruth Vinall, Associate Professor, California Northstate University College of Pharmacy (CNUCOP), Elk Grove, CA 95757, USA

\begin{abstract}
A significant number of prostate cancer patients use complementary alternative medicines (CAMs) as an adjunct to their conventional treatment. Examples of CAMs that are frequently used by prostate cancer patients include green tea extract, lycopene, and pomegranate fruit extract. In many cases there is little if any clinical study-based evidence to support the efficacy of CAMs in this setting, and, importantly, some CAMs can cause serious adverse effects when taken a high doses and/or have significant drug interactions. The latter is an important consideration in this patient group as most patients are older and take multiple medications in addition to their anti-cancer drugs. This review summaries prostate cancer patient clinical trial data that is available for CAMs which are commonly used by prostate cancer patients, and provides dose, dose form, adverse effect, and drug interaction data. Providing evidence-based guidance regarding CAMs to prostate cancer patients can potentially improve patient outcomes, including the avoidance of adverse effects and drug interactions which impact drug efficacy.
\end{abstract}

\section{Keywords}

Prostate cancer, Complementary alternative medicines, Efficacy, Drug interactions, Adverse effects

\section{Introduction}

Prostate cancer $(\mathrm{PC})$ is the second most frequently diagnosed cancer in men [1]. The median age at diagnosis is 66 and major risk factors include age, family his- tory, and race (it is more common in African American men) [1]. In 2015, there were approximately 1,735,350 new cases diagnosed and it is estimated that $11.6 \%$ of men will be diagnosed with PC at some point during their lifetime [2]. Advances in early detection and treatment have contributed to improved patient outcomes; in 1980 the 5-year survival rate was $\sim 70.2 \%$, the most recent statistics estimate 5 -year survival at $99.0 \%[2,3]$. These advances have resulted in there being a huge number of men in the US living with PC. Many of these patients (estimated at between $9-64 \%$ by various studies), as well as men at high risk of developing PC, use complementary alternative medicines (CAMs) as an adjunct to their treatment, and the majority of patients (estimated at $75 \%$ ) will do so without informing their doctor [4-7]. Questionnaire-based studies indicate that PC patients take CAMs for a variety of reasons, including to ameliorate treatment-associated side effects, to reduce the risk of disease progression, and to increase their sense of having control over their disease and its treatment [8]. A major issue is that typically patients assume, often incorrectly, that CAMs are completely harmless and will not cause any adverse effects. This review names and describes several CAMs that are frequently used by men with $P C$ and/or men at high risk of $\mathrm{PC}$; green tea, modified citrus pectin (MCP), pomegran-

Citation: Deol H, Truong A, Woldemariam T, Feng X, Vinall R (2018) Supporting Evidence, Potential Adverse Effects, and known Drug Interactions of the Complementary Alternative Medicines which are Frequently used by Prostate Cancer Patients. Int Arch Urol Complic 4:047. doi.org/10.23937/2469$5742 / 1510047$

Accepted: October 16, 2018: Published: October 18, 2018

Copyright: (C) 2018 Deol H, et al. This is an open-access article distributed under the terms of the Creative Commons Attribution License, which permits unrestricted use, distribution, and reproduction in any medium, provided the original author and source are credited. 
ate fruit extract (PFE), lycopene, soy, vitamin D, sulphoraphane, selenium, vitamin $\mathrm{E}$, and saw palmetto. Data from peer-reviewed questionnaire studies which report the frequency of CAM usage by PC patients is available for some of these; selenium (4.1-26.6\%; 11 studies, total $n=7,109$ patients), vitamin $E(5-53.3 \%$; 8 studies, total $n=3,261)$, saw palmetto $(1.9-24.5 \% ; 11$ studies, total $n=6,525$ patients), green tea (51\%; 1 study, $n=$ 451 patients), lycopene (31\%; 1 study, $n=451$ patients) $[5,9]$. The other CAMs reviewed here are frequently discussed in online PC patient discussion boards and have been the focus of multiple clinical, epidemiological, and in vitro studies indicating that they are also relevant to the PC community. This review provides information regarding the clinical evidence supporting usage of these
CAMs as well as information regarding dosage forms, dosing, potential side effects and potential drug interactions. While none of the CAMs discussed have a validated drug interaction with PC standard of care therapies, PC patients often have comorbidities (e.g. hypertension ( $\sim 2 \%$ of patients), diabetes ( $11 \%$ of patients), and congestive heart failure (CHF)/valvular disease ( $5 \%$ of patients) [10], and an interaction with a drug used to treat these co-morbidities could thereby indirectly impact their PC treatment and outcomes. For example, green tea, PFE, soy, vitamin D, vitamin E, and lycopene all have validated drug interactions with drugs commonly used to treat hypertension (Table 1). A summary of the dose forms available for each CAM as well as potential side effects and potential drug interactions are provided in

Table 1: Potential benefits, dose forms available, and potential side effect/drug interaction data for CAMs used by prostate cancer patients as part of their treatment regimen (note that the potential drug interaction list does not include drugs which are used to treat prostate cancer, however, many of these drugs are used to treat co-morbidities that prostate cancer patients frequently experience and may therefore meaning these CAMs may indirectly interfere with their prostate cancer treatment). A drug interaction is defined as an interaction between the CAM and the drug which may either increase treatment-associated toxicity and/or decrease drug efficacy.

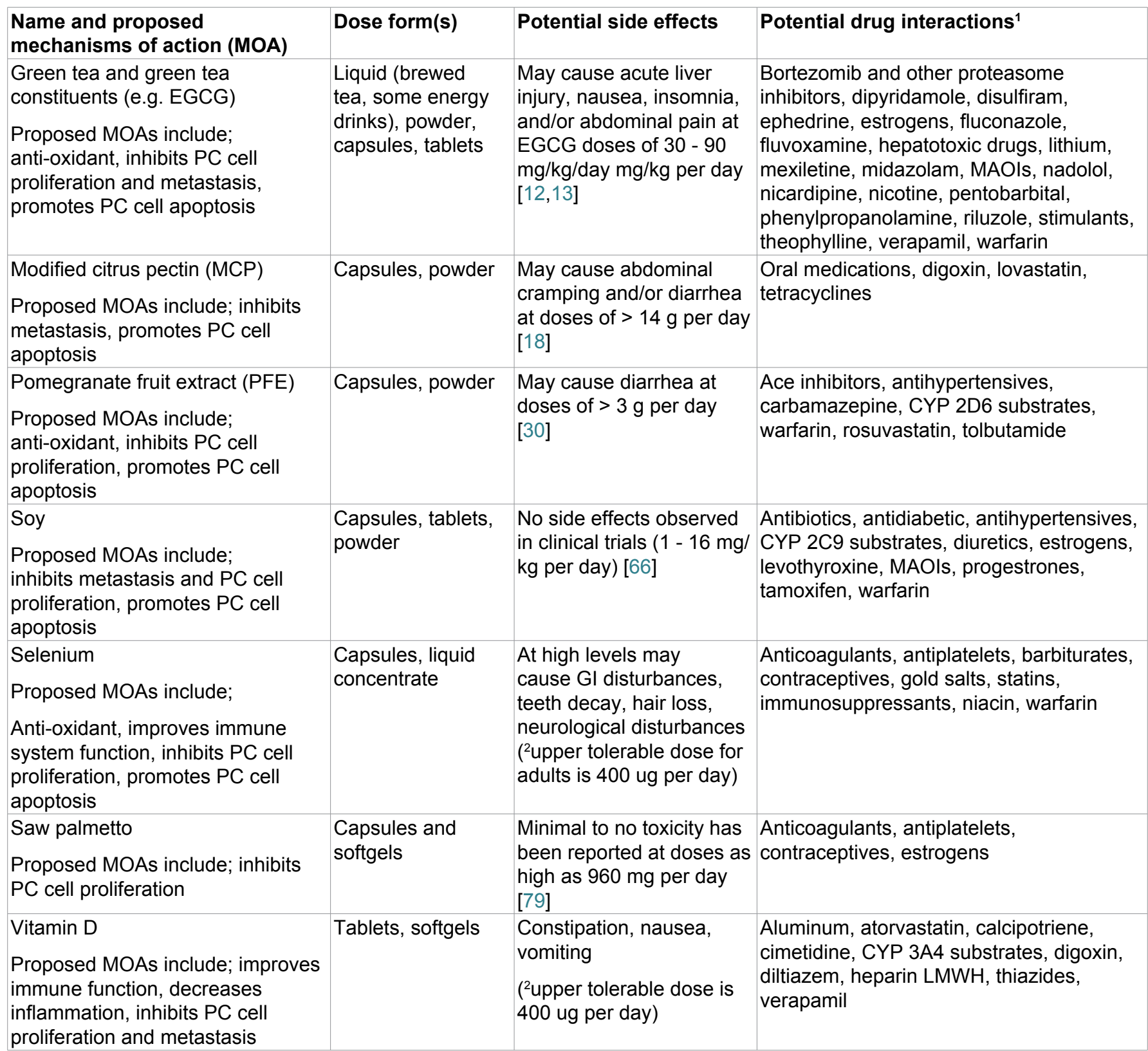




\begin{tabular}{|l|l|l|l|}
\hline $\begin{array}{l}\text { Vitamin E } \\
\text { Proposed MOA; anti-oxidant }\end{array}$ & $\begin{array}{l}\text { Capsules, tablets, } \\
\text { liquid concentrate }\end{array}$ & $\begin{array}{l}\text { May cause nausea and } \\
\text { upset stomach (2upper } \\
\text { tolerable dose is 1,000 mg } \\
\text { per day) }\end{array}$ & $\begin{array}{l}\text { Anticoagulants, antiplatelets, cyclosporine, } \\
\text { CYP 3A4 substrates, statins, niacin, } \\
\text { warfarin }\end{array}$ \\
\hline $\begin{array}{l}\text { Lycopene } \\
\text { Proposed MOA; anti-oxidant }\end{array}$ & $\begin{array}{l}\text { Capsules, tablets, } \\
\text { liquid concentrate }\end{array}$ & $\begin{array}{l}\text { May cause nausea, } \\
\text { headache, diarrhea, and } \\
\text { upset stomach at } ~ 120 \\
\text { mg per day [54] }\end{array}$ & No known drug-drug interactions \\
\hline $\begin{array}{l}\text { Sulforaphane } \\
\text { Proposed MOA; histone } \\
\text { deacetylase (HDAC) inhibitor, } \\
\text { inhibits cell proliferation }\end{array}$ & Capsules & $\begin{array}{l}\text { May cause bloating at } 60 \\
\text { mg per day [94] }\end{array}$ & $\begin{array}{l}\text { Clozapine, cyclobenzaprine, fluvoxamine, } \\
\text { haloperidol, imipramine, mexiletine, } \\
\text { olanzapine, pentazocine, propranolol, } \\
\text { tacrine, theophylline, zileuton, zolmitriptan }\end{array}$ \\
\hline
\end{tabular}

${ }^{1}$ data was obtained from https://naturalmedicines.therapeuticresearch.com;

${ }^{2}$ https://ods.od.nih.gov/factsheets.

Table 2: Summary of prostate cancer-related clinical trial data (primary and secondary prevention studies) that is available for frequently used complementary alternative medicines (CAMs).

\begin{tabular}{|c|c|c|}
\hline CAM & $\begin{array}{l}\text { Number of clinical studies, level of evidence, number of patients enrolled (n), } \\
\text { and primary clinical outcome measure that was assessed }\end{array}$ & Outcome \\
\hline Green tea & $\begin{array}{l}\text { Two clinical studies; } \\
\text { Clinical study } 1 \text { : level } 1 \text { evidence, } n=97 \text {, primary outcome measure was } \\
\text { progression of HGPIN to PC [16]. } \\
\text { Clinical study } 2 \text { : level } 3 \text { evidence, } n=42 \text {, primary outcome measure was } 50 \% \\
\text { reduction in baseline PSA level [17]. }\end{array}$ & $\begin{array}{l}\text { None of these studies } \\
\text { showed efficacy }\end{array}$ \\
\hline $\begin{array}{l}\text { Modified citrus } \\
\text { pectin (MCP) }\end{array}$ & $\begin{array}{l}\text { Two clinical studies; } \\
\text { Clinical study } 1 \text { : level } 3 \text { evidence, } n=13 \text {, primary outcome measure was increase in } \\
\text { PSADT [18]. } \\
\text { Clinical study } 2 \text { : level } 3 \text { evidence, } n=49 \text {, outcome was tumor response per RESIST } \\
\text { criteria [24]. }\end{array}$ & $\begin{array}{l}\text { Only study } 1 \text { showed } \\
\text { efficacy }\end{array}$ \\
\hline $\begin{array}{l}\text { Pomegranate fruit } \\
\text { extract (PFE) }\end{array}$ & $\begin{array}{l}\text { Four clinical studies; } \\
\text { Clinical study } 1 \text { : level } 3 \text { evidence, } n=46 \text {, outcome measure was reduction in PSA } \\
\text { levels [27]. } \\
\text { Clinical study } 2 \text { : level } 3 \text { evidence, } n=104 \text {, outcome measure was increase in } \\
\text { PSADT [30]. } \\
\text { Clinical study } 3 \text { : level } 1 \text { evidence, } n=70 \text {, outcome measure was a reduction in } \\
\text { oxidative stress markers in patient tumors [31]. } \\
\text { Clinical study } 4 \text { : level } 1 \text { evidence, } n=102 \text {, outcome measure was increase in } \\
\text { PSADT [32]. }\end{array}$ & $\begin{array}{l}\text { Only studies } 1 \text { and } 2 \\
\text { showed efficacy }\end{array}$ \\
\hline Selenium & $\begin{array}{l}\text { Four clinical studies: } \\
\text { Clinical study } 1 \text { : level } 1 \text { evidence, } n=35,533 \text {, outcome measure was PC incidence } \\
\text { [39]. } \\
\text { Clinical study } 2 \text { : level } 1 \text { evidence, } n=423 \text {, outcome measure was PC incidence } \\
\text { [38]. } \\
\text { Clinical study } 3 \text { : level } 1 \text { evidence, } n=699 \text {, outcome measure was PC incidence } \\
\text { [38]. } \\
\text { Clinical study } 4 \text { : level } 1 \text { evidence, } n=1,561 \text {, outcome measure was PC incidence } \\
\text { [38]. }\end{array}$ & $\begin{array}{l}\text { None of these studies } \\
\text { showed efficacy }\end{array}$ \\
\hline Vitamin $\mathrm{E}$ & $\begin{array}{l}\text { Two clinical studies: } \\
\text { Clinical study } 1 \text { : level } 1 \text { evidence, } n=35,533 \text {, outcome measure was PC incidence } \\
\text { [39]. } \\
\text { Clinical study } 2 \text { : level } 1 \text { evidence, } n=14,641 \text {, outcome measure was PC incidence } \\
\text { [45]. }\end{array}$ & $\begin{array}{l}\text { None of these studies } \\
\text { showed efficacy }\end{array}$ \\
\hline Lycopene & $\begin{array}{l}\text { Three clinical studies: } \\
\text { Clinical study } 1 \text { : level } 1 \text { ii evidence, } n=41 \text {, outcome measure was decrease in PSA } \\
\text { levels [52]. } \\
\text { Clinical study } 2 \text { : level } 1 \text { ii evidence, } n=36 \text {, outcome measure was decrease in PSA } \\
\text { levels [53]. } \\
\text { Clinical study } 3 \text { : level } 1 \text { ii evidence, } n=71 \text {, outcome measure was decrease in PSA } \\
\text { levels [54]. }\end{array}$ & $\begin{array}{l}\text { Only study } 3 \text { showed } \\
\text { efficacy }\end{array}$ \\
\hline
\end{tabular}




\begin{tabular}{|c|c|c|}
\hline Soy & $\begin{array}{l}\text { Eight clinical studies; } \\
\text { Clinical study } 1 \text { : level } 1 \text { evidence, } n=66 \text {, outcome measure was decrease in PSA } \\
\text { level [67]. } \\
\text { Clinical study } 2 \text { : level } 1 \text { evidence, } n=53 \text {, outcome measure was decrease in sex } \\
\text { hormone-binding globulin [68]. } \\
\text { Clinical study } 3 \text { : level } 1 \text { evidence, } n=45 \text {, outcome measure was decrease in sex } \\
\text { hormone-binding globulin [69]. } \\
\text { Clinical study } 4 \text { : level } 1 \text { evidence, } n=47 \text {, outcome measure was decrease in PSA } \\
\text { levels [70]. } \\
\text { Clinical study } 5 \text { : level } 1 \text { evidence, } n=158 \text {, outcome measure was decrease in PSA } \\
\text { levels [71]. } \\
\text { Clinical study } 6 \text { : level } 1 \text { evidence, } n=29 \text {, outcome measure was decrease in PSA } \\
\text { levels [72]. } \\
\text { Clinical study } 7 \text { : level } 1 \text { evidence, } n=66 \text {, outcome measure was decrease in } \\
\text { circulating androgen levels [73]. } \\
\text { Clinical study } 8 \text { : level } 1 \text { evidence, } n=76 \text {, outcome measure was decrease in PSA } \\
\text { levels [74]. }\end{array}$ & $\begin{array}{l}\text { Only studies } 4,6 \text {, and } \\
7 \text { showed efficacy. } \\
\text { Meta-analysis of } \\
\text { all } 8 \text { studies was } \\
\text { inconclusive }\end{array}$ \\
\hline $\begin{array}{l}\text { Saw palmetto } \\
\text { extract }\end{array}$ & $\begin{array}{l}\text { One clinical study: level } 1 \text { evidence, } n=369 \text {, outcome measures were AUA } \\
\text { symptom score and PSA levels [77]. }\end{array}$ & Did not show efficacy \\
\hline Vitamin D & $\begin{array}{l}\text { Three clinical studies; } \\
\text { Clinical study } 1 \text { : level } 3 \text { evidence, } n=21 \text {, outcome measure was decrease in PSA } \\
\text { levels [85]. } \\
\text { Clinical study } 2 \text { : level } 3 \text { evidence, } n=18 \text {, outcome measure was decrease in PSA } \\
\text { levels [86]. } \\
\text { Clinical study } 3 \text { : level } 1 \text { evidence, } n=52 \text {, outcome measures were decrease in PSA } \\
\text { levels and Gleason score [85]. }\end{array}$ & $\begin{array}{l}\text { Studies } 1 \text { and } 3 \\
\text { showed efficacy }\end{array}$ \\
\hline Sulforaphane & $\begin{array}{l}\text { Two clinical studies; } \\
\text { Clinical study } 1 \text { : level } 3 \text { evidence, } n=20 \text {, outcome measure was PSADT [93]. } \\
\text { Clinical study } 2 \text { : level } 1 \text { evidence, } n=78 \text {, outcome measure was decreased PSA } \\
\text { level [94]. }\end{array}$ & $\begin{array}{l}\text { Study } 1 \text { showed } \\
\text { efficacy }\end{array}$ \\
\hline
\end{tabular}

HGPIN: High Grade Prostatic Intraepithelial Neoplasia; PC: Prostate Cancer; PSADT: PSA Doubling Time.

Table 1, data from both primary and secondary prevention clinical studies is summarized in Table 2.

Green Tea (Camellia sinensis, synonyms Camellia thea, Camellia theifera, Thea bohea, Thea sinensis, Thea viridis. Family: Theaceae)

Green tea contains several flavonoid polyphenols, the most important of which is thought to be epigallocatechin-3-gallate (EGCG), as well as caffeine. The content of each of these can vary widely between products. Typically, an $8 \mathrm{fl}$. oz cup of brewed green tea contains 200 - $300 \mathrm{mg}$ flavonoids, 300 - $400 \mathrm{mg}$ polyphenols (8 $12 \%$ of which is EGCG), and $25 \mathrm{mg}$ caffeine. There have been multiple reports of EGCG-related toxicity. The usual range of EGCG-related toxicity is $30-90 \mathrm{mg} / \mathrm{kg}$ daily in humans, and multiple studies have reported hepatotoxicity in patients consuming EGCG-containing products $[11,12]$. It is noteworthy that the authors state that some of these cases may have resulted from drug interactions (please refer to Table 1 for a list of drugs that are commonly taken by PC patients to treat comorbidities and which have drug interactions with green tea and/or other CAMs). Flavonoids and polyphenols have anti-oxidant properties which may help reduce cancer risk by neutralizing free radical-induced damage. Multiple cell line, animal model, and epidemiological studies have shown a link between free radical activity/levels and in- cidence and progression of PC $[13,14]$, and indicate constituents of green tea can inhibit cell proliferation and metastasis, promote apoptosis and inhibit 5-alpha reductase activity (the enzyme that catalyzes conversion of testosterone to dihydrotestosterone (DHT)).

\section{Epidemiological and clinical data}

While several epidemiological studies have shown a link between green tea consumption and reduced incidence of PC, others have shown no benefit. A meta-analysis of studies in which participants consumed $>3$ cups of green tea per day showed no benefit in terms of PC risk reduction [15]. There have 2 clinical trials. The first study, a randomized, placebo-controlled, double-blind trial of EGCG (400 mg/day) of men at high risk of developing PC (97 patients, total, level 1 evidence), showed no difference in the number of PC cases between the treatment and placebo group after 1 year [16] and there was no difference in adverse event rate between the 2 groups. In a phase two clinical trial of 42 patients with advanced PC (non-controlled, level 3 evidence), green tea failed to show antineoplastic activity [17]; only 1 patient experienced a $50 \%$ decrease in PSA (note the median time on study was only 1 month). Sixty-nine percent of patients who participated in this study experienced a grade 1 or 2 toxicity that manifested as nausea, emesis, insomnia, fatigue, diarrhea, abdominal pain, or confusion, and this is likely due to the high dosage of green 
tea that participants received; 6 grams of green tea per day orally in 6 divided doses.

\section{Modified Citrus Pectin (MCP) (Pectin)}

Citrus pectin is a naturally occurring indigestible complex polysaccharide that is found in the peel and pulp of citrus fruits [18]. Exposure of citrus pectin to high $\mathrm{pH}$ and high temperature produces modified citrus pectin (MCP) and, unlike regular citrus pectin, this is readily absorbed into the gastrointestinal tract [11]. Several cell line and animal studies have demonstrated MCP can delay or prevent PC cell movement and metastasis via antagonizing beta-galactoside binding protein galectin-3 (Gal-3), a molecule that is present on endothelial cells which line blood vessels [19-23]. These studies indicate MCP prevents cancer cells from adhering to blood vessel walls and metastasizing. Cell line studies have shown MCP can also promote apoptosis of PC cells by causing activation of caspase 3 [23]. Epidemiological and clinical data: Two non-controlled phase II clinical studies have been performed in PC patients, and one of these showed efficacy (note that both studies enrolled a limited number of patients and had a relatively short follow-up period, level 3 evidence). Grade 1 and 2 toxicities were observed in both studies. Guess, et al. conducted a phase II pilot study to evaluate MCP use in PC patients who had failed local curative therapy (total of 13 patients) [18]. Patients were asked to take six $800 \mathrm{mg}$ capsules 3 times per day (total of $14.4 \mathrm{~g}$ of MCP per day) for a 12-month period. Three patients withdrew early due to side effects, noted mostly as either abdominal cramps and/or diarrhea. Seven out of the 10 patients remaining patients had a statistically significant decrease in PSA doubling time (PSADT, the primary endpoint of the study). There was no long-term follow-up of these patients to determine whether or not they developed metastases. A pilot study which included 10 PC patients (and an additional 39 patients with other solid tumor types) found that one PC patient experienced a $50 \%$ decrease in PSA levels 16 weeks after initiating treatment [24]. Patients were treated with 5 g MCP 3 times per day (15 g per day, total) over a 24-week period. No differences in PSA levels were observed in the other 9 PC patients over the 24-week period. Out of the 49 patients enrolled in this study, 11 patients experience grade 1 or 2 adverse events which manifested as dyspepsia, pruritus, nausea, constipation, and weight loss. One patient experienced a grade 3 adverse event; pruritus.

\section{Pomegranate Fruit Extract (PFE) (Punica gra- natum. Family: Lythraceae or Punicaceae)}

Pomegranate fruit and pomegranate fruit extract (PFE) are rich in flavonoids and polyphenols as well as important minerals such as potassium and magnesium. The part of the pomegranate fruit that is usually consumed, the red seeds, may be eaten raw or made into juice/juice concentrate. PFE is made from the entire pomegranate including the peel. This is important because punicalagin, a polyphenol that is thought to be the primary component responsible for the anti-oxidant and anti-inflammatory properties of pomegranate fruit, is found primarily in the pomegranate peel. It should be noted that there can be significant variation in the punicalagin content of pomegranates fruits depending on their ripeness, growing region, and storage amongst other things. A study of pomegranate fruit juice and PFE capsules determined that pomegranate fruit juice typically contains between 9 - $310 \mathrm{mg} / \mathrm{L}$ punicalagins, while fruit juice concentrates contain between 1400 - $29900 \mathrm{mg} / \mathrm{L}$ and PFE capsules contain between 38400 - 103000 mg/kg [25]. Consumption of $>3000 \mathrm{mg} /$ day of PFE has been associated with diarrhea, but otherwise no serious side effects have been reported [25]. Cell line and animals studies have shown that PFE can reduce PC cell proliferation and induce PC cell death $[26,27]$. PFE has also been shown to reduce expression levels of androgen-synthesizing genes and NF-kappaB activity in PC cell lines [28,29].

\section{Epidemiological and clinical data}

A total of 4 clinical trials have been performed. The first 2 of these provided level 3 evidence demonstrating efficacy, however, 2 subsequent randomized, controlled, blinded studies (level 1 evidence) failed to show efficacy. Only a few patients experienced grade 1 or 2 toxicities in these studies. In the first study, a non-controlled phase II clinical trial in men with rising PSA after surgery or radiation therapy (level 3 evidence) in which patients were asked to consume 6 - $8 \mathrm{fl} \mathrm{oz} \mathrm{of} \mathrm{pome-}$ granate juice per day for a 2 year period, 16 of the 46 enrolled patients achieved a decrease in PSA levels (4 patients achieved a greater than $50 \%$ reduction) [27]. No serious adverse events were recorded, and the authors reported that the treatment was well tolerated. Another non-controlled phase II trial (level 3 evidence), conducted in 104 men with rising PSA levels without metastases over an 18 month period, showed that consumption of higher levels of PFE (1 versus 3 grams, daily) resulted in a significant increase in PSA doubling times regardless of the dose taken [30]. Diarrhea was seen in $1.9 \%$ of patients taking $1 \mathrm{~g} /$ day and in $13.5 \%$ of patients taking $3 \mathrm{~g} /$ day. A subsequent double-blind, randomized clinical study (level 1 evidence) of 70 men with PC who took PFE (2 grams/day) for 4 weeks prior to radical prostatectomy, observed no difference between groups [31]. Four of the patients in the treatment arm experienced diarrhea versus 2 in the placebo arm. Lastly, a double-blind, randomized phase Ilb clinical trial of 102 PC patients (the majority of whom had castration resistant PC (68\%), level 1 evidence) showed no difference in PSA kinetics between patients who consumed $500 \mathrm{ml} /$ daily of pomegranate juice for 4 weeks versus those who consumed a placebo control [32]. One patient in the treatment group reported diarrhea.

\section{Selenium (Selenium, Se, Atomic number 34)}

Selenium is a naturally occurring trace mineral that 
is present in both organic forms and inorganic forms in many food types as well as water $[33,34]$. According the World Health Organization (WHO), typical concentration ranges of selenium in water, meats/seafood and cereal are 0.06 - $400 \mathrm{ug} / \mathrm{l}, 0.3-0.5 \mathrm{mg} / \mathrm{kg}$, and $0.1-10 \mathrm{mg} /$ $\mathrm{kg}$, respectively. Fruits/vegetables typically have $<0.01$ $\mathrm{mg} / \mathrm{kg}$ selenium. While selenium is essential for good health it is extremely toxic at higher concentrations. In animal studies the lethal dose is reported as $1.5-6 \mathrm{mg} /$ kg body weight, and the lowest observed adverse effect level is $0.03 \mathrm{mg} / \mathrm{kg}$ body weight/day. The US Institute of Medicine has set $400 \mathrm{ug} /$ day as the tolerable upper intake level for humans. High dietary intake in humans has been reported to cause gastrointestinal disturbances, skin discoloration, teeth decay, hair loss, brittle nails, and neurological disturbances. Multiple studies have focused on the role of selenium in cancer prevention, including PC prevention. Cell line and animal studies have shown that selenium can affect DNA stability, cell proliferation, and apoptotic cell death as well as regulate oxidative stress and immune system function [35].

\section{Epidemiological and clinical data}

A meta-analysis comparing 17 epidemiological studies that assessed the relationship between selenium intake and PC indicates that there is an association between selenium intake and decreased PC incidence (OR $=0.76,95 \% \mathrm{Cl} 0.64,0.91$ ) [36], however, others have noted epidemiological studies of selenium should be interpreted with caution due to the difficulty of accurately estimating selenium levels in patients and/or estimating intake [37]. There have been a total of 5 clinical trials, including a controlled, randomized, double-blind phase III clinical trial (the Selenium and Vitamin E Cancer Prevention Trial (SELECT), level 1 evidence) and all of these trials determined that selenium did not decrease PC incidence [38]. The SELECT trial included 35,533 men greater than 50 years of age that were not at high risk for prostate cancer. The products were tested in 4 treatment arms: placebo, Vitamin E, selenium, and combination treatment. The trial was planned to last 11 years but was ended at 7 years since there was no observed benefit from any of the treatments [39]. It is noteworthy that a subsequent case-cohort study (level 3 evidence) determined that selenium supplementation in men with high baseline selenium levels increased the risk of high-grade PC [40].

\section{Vitamin E}

Vitamin E comprises of several fat soluble anti-oxidants molecules, including tocopherol isoforms and tocotrienol, which are found in fat-containing foods (e.g. vegetable oils and nuts) [41]. The majority of studies, including clinical studies, have focused on alpha-tocopherol (also known as APC-100) and it is the form found in most vitamin E supplements. Multiple cell line and animal studies shown that alpha-tocopherol has anti-oxidant activity which can decrease oxidative stress and inhibit inflammatory processes associated with PC incidence and progression [41,42]. Recent studies demonstrate that other isoforms (primarily the gamma-tocopherol isoform but also alpha-tocopherol and tocopherol isoform mixtures) also have strong anti-oxidant activity and have anti-cancer activities in PC cell line and mouse models $[43,44]$.

\section{Epidemiological and clinical data}

Level 1 evidence from two controlled, randomized, placebo-controlled clinical trials (level 1 evidence) shows that vitamin E does not affect PC incidence $[38,45]$. The Selenium and Vitamin E Cancer Prevention Trial (SELECT)) tested 4 treatment arms: placebo, vitamin E (400 IU/day), selenium, and combination treatment. A total of 35,533 men greater than 50 years of age that were not at high risk for prostate cancer participated in the study. The trial was planned to last 11 years but was ended at 7 years since there was no observed benefit from any of the treatment's selenium or vitamin $\mathrm{E}$. The Physician's Health Study II tested 2 treatment arms: placebo and vitamin E (400 IU/day). A total of 14,641 men greater than 50 years old enrolled and were followed for 8 years. Again, no difference in PC incidence was observed between the groups. The recommended upper tolerable dose per day is $1000 \mathrm{mg}$ [46].

\section{Lycopene (All-Trans Lycopene)}

Lycopene a carotenoid that is found in many fruits and vegetables including tomatoes. The average content in a ripe tomato is $\sim 120 \mathrm{mg} / \mathrm{kg}$ although content can vary widely based on geographical location and species. It is noteworthy that processed tomato products such as juices and tomato paste allow for greater absorption and bioavailability of lycopene compared to raw tomatoes. Multiple cell line and animal studies have shown that lycopene is an anti-oxidant which can reduce oxidative stress in PC cells $[47,48]$.

\section{Epidemiological and clinical data}

The majority of epidemiological studies have shown an association between lycopene intake and decreased PC incidence or progression [49-51]. A total of 3 phase Il clinical trials of lycopene as a single agent have been conducted. Grainger, et al. enrolled 41 PC patients, 20 of whom were treated with lycopene (> $25 \mathrm{mg} /$ day) and 21 with soy protein over a 2-month period (controlled, randomized, non-blinded; level 1ii evidence) [52]. 5 out of 20 patients in the lycopene arm experienced decreased PSA levels. Clark, et al. enrolled 36 PC patients. Six cohorts of 6 patients were treated with 15, 30, 45, 60, 90 or $120 \mathrm{mg} /$ day for 1 year (controlled, randomized, non-blinded; level 1ii evidence). In this study efficacy was not shown and there was no PSA response, [53]. Vaishampayan, et al. enrolled 71 PC patients, 38 were treated with lycopene alone $(15 \mathrm{mg} /$ day) and 33 were treated with lycopene + soy isoflavones (controlled, randomized, non-blinded; level $1 \mathrm{ii}$ evidence) [54]. 95\% of 
the patients achieved PSA stabilization, however, partial response (50\% reduction in PSA levels) and complete responses $(<4 \mathrm{ng} / \mathrm{ml}$ PSA) were not observed. The doses of lycopene administered in these clinical trials was well tolerated, a minimal number of patients experience GI upset or headache (reported as grade I toxicities).

Soy (Glycine max, Family: Fabaceae/Leguminosae)

Soy products are derived from the soybean, a legume that is native to East Asia but is now grown throughout the world. Soybeans and soybean products such as tofu, soy milk and fermented soybean (e.g. natto and tempeh) are a good source of protein, dietary fiber, vitamins (including B vitamins), and isoflavones. Isoflavones are thought to be the main component responsible for soy's anticancer properties, and of these genistein is the most well studied. Multiple observational studies, and a recent meta-analysis of observational studies (level 3 evidence), have demonstrated that consumption of soy products is associated with decreased risk of prostate cancer [55]. Cell line studies indicate that genistein can inhibit prostate cancer cell growth, cell survival, and metastasis [56-60] through multiple mechanisms including decreasing androgen receptor (AR) levels/activity, inhibition of the Akt and NFkappaB pathways, and decreasing VEGF and MMP production, respectively. Animal studies have produced less consistent results with some studies showing decreased tumorigenesis and other showing no impact or even promotion of tumorigenesis [61-64]. In regards to the latter, it has been suggested that genistein should be taken in combination with other soy isoflavones to counteract its tumorigenic effects [61]. It is noteworthy that soy does have weak estrogenic activity, however, the link between estrogen levels and PC remains controversial with some studies showing an association and showing no association [65].

\section{Epidemiological and clinical data}

Multiple small clinical studies have been conducted, including 8 randomized controlled trials (RCT, level 1 evidence) in which prostate cancer patients were treated with soy or soy isoflavones [66]. Primary clinical endpoints included decrease in PSA levels, alterations in sex hormone binding albumin, and alterations in circulating androgen levels ([67-74]. Three of the 8 studies showed efficacy, however, a meta-analysis of all 8 RCT was inconclusive in regard to efficacy (level 1 evidence); significance was not achieved. It should be noted that time on study was short (e.g. 3 - 6 weeks) for many of these studies. It is noteworthy that the meta-analysis did confirm that soy and soy isoflavones have a good safety profile in the study population [66].

Saw Palmetto Extract (Serenoa repens, Family: Arecaceae/Palmae)

Saw palmetto extract is obtained from berries of the saw palmetto tree (Serenoa repens). Saw palmet- to is rich in a variety of plant sterols and several cell line studies have shown that some of these, including chalcanonol glycoside, beta-sitosterol and stigmasterol, have antiproliferative effects in prostate cancer cell lines $[75,76]$. Despite this, no benefit has been observed in epidemiological or clinical studies.

\section{Epidemiological and clinical data}

An epidemiological study conducted by Bonnar-Pizzorno, et al. found no association between saw palmetto use and prostate cancer risk (in 35,171 men between ages 50-76) [77]. In a controlled, randomized, double-blind clinical study conducted by Andriole, et al. (CAMUS trial) which recruited 369 patients, dose escalation of saw palmetto did not affect AUA symptom scores or PSA levels more than placebo itself (controlled, randomized, double-blind; level 1 evidence) [78]. It is noteworthy that in an analysis of safety and toxicity on the CAMUS trial, Avins, et al. found no evidence of toxicity from saw palmetto use over 18 months, even at increased dosages [79].

Vitamin D (25-hydroxycholecalciferol, Calcipotriene, Calcitriol, Cholecalciferol, Ergocalciferol)

Vitamin $D$ is a fat-soluble vitamin that is naturally produced by the body when exposed to sunlight and is essential for good health; it plays key roles in calcium absorption, maintenance of adequate calcium and phosphate levels, immune function, and reduction of inflammation. Cell line studies have demonstrated that vitamin D can inhibit PC cell proliferation and metastasis $[80,81]$. Animal study data have been conflicting, with some data showing that vitamin $\mathrm{D}$ can prevent metastasis and others showing the opposite [82,83].

\section{Epidemiological and clinical data}

While multiple epidemiological studies have reported an association between vitamin $D$ and decreased prostate cancer risk, a recent meta-analysis showed that the collective data do not support this association [84]. A limited number of clinical intervention studies have been performed. One phase II trial with 21 prostate cancer patients on calcitriol (the active form of vitamin D3) and naproxen for progressive prostate cancer saw prolongation of PSA doubling time in $75 \%$ of the patients (non-controlled; level 3 evidence) [85]. Another phase II trial by Chadha, et al. (18 patients with castration resistant prostate cancer) showed no impact of calcitriol on PSA levels (non-controlled; level 3 evidence) [86]. Data from an ongoing randomized controlled trial by Hollis, et al. indicate that consumption of 4000 units/ day of vitamin D3 or placebo in patients scheduled for elective prostatectomies (37 patients) may be able to keep low-grade prostate cancers from progressing (level 1 evidence) [87]. This is supported by a previous study that came to a similar conclusion with 24 out of 55 sub- 
jects showing an improvement with no adverse effects reported [88]. It is noteworthy that vitamin D3 can influence metal homeostasis, and a recent study showed that consumption of high doses (2000 IU) can cause lead accumulation in PC patients [89].

\section{Sulphoraphane (Isothiocyanate present in many cruciferous vegetables)}

Sulphoraphane is an organosulfur isothiocyanate which is found in cruciferous vegetables that belong to the gemmifera family (Brassica oleracea), e.g. broccoli, brussel sprouts, and cabbages. These vegetables typically contain $\sim 1 \mathrm{uM} / \mathrm{g}$ of sulphoraphane [90]. It should be noted that cooking may decrease their sulphoraphane content [90]. Multiple in vitro studies have shown that sulforaphane can act as a histone deacetylase inhibitor (HDACi) and thereby cause decreased proliferation of PC cells [91]. Efficacy has also been observed in animal models [91].

\section{Epidemiological and clinical data}

A recent meta-analysis showed that consumption of cruciferous vegetables is associated with a reduction in PC risk [92]. It should be noted that these epidemiological studies were not limited to cruciferous vegetables which contain sulphoraphane. There have been two prospective studies of sulphoraphane in PC patients. A phase II study of 20 PC patients demonstrated that treatment with $200 \mathrm{uM}$ of sulphoraphane per day mediated a significant lengthening in PSA doubling times (non-controlled; level 3 evidence) [93]. A subsequent controlled, randomized, double-blind phase III study (level 1 evidence) of 78 PC patients failed to reach statistical significance; treatment with $60 \mathrm{mg}$ sulphoraphane per day did not cause a statistically significant decrease in PSA levels compared to a placebo group [94].

\section{Conclusions}

The level of evidence available to support the efficacy and effectiveness of these CAMs varies widely and conveying this information to PC patients may help guide their selection of a particular CAM. While many of the level 1 evidence studies failed to show efficacy, it should be noted that several of these had relatively short follow-up periods and so should be interpreted with caution. Importantly, some CAMs have significant toxicities if consumed at higher doses as well as drug interactions with medications that PC patients may be taking. Providing counseling to PC patients regarding CAM selection and usage could help prevent adverse events and help ensure the efficacy of anti-cancer therapies are not impacted.

\section{References}

1. http://seer.cancer.gov/csr/

2. Siegel RL, Miller KD, Jemal A (2018) Cancer statistics, 2018. CA Cancer J Clin 68: 7-30.
3. Howlader N, Noone AM, Krapcho M, Garshell J, Miller D, et al. (2012) SEER Cancer statistics review, 1975-2012, National Cancer Institute. Bethesda MD.

4. Barnes PM, Bloom B, Nahin R (2008) Complementary and alternative medicine use among adults and children: United States, 2007. Natl Health Stat Report 12. 1-23

5. Eng J, Ramsum D, Verhoef M, Guns E, Davison J, et al. (2003) A population-based survey of complementary and alternative medicine use in men recently diagnosed with prostate cancer. Integr Cancer Ther 2: 212-216.

6. Jones HA, Metz JM, Devine P, Hahn SM, Whittington R (2002) Rates of unconventional medical therapy use in patients with prostate cancer: Standard history versus directed questions. Urology 59: 272-276.

7. Ramsey SD, Zeliadt SB, Blough DK, Fedorenko CR, Fairweather ME, et al. (2012) Complementary and alternative medicine use, patient-reported outcomes, and treatment satisfaction among men with localized prostate cancer. Urology 79: 1034-1041.

8. Egger S, Hughes S, Smith DP, Chambers S, Kahn C, et al. (2018) Factors associated with the use of complementary and alternative medicines for prostate cancer by long-term survivors. PLoS One 13: e0193686.

9. Bishop FL, Rea A, Lewith H, Chan YK, Saville J, et al. (2011) Complementary medicine use by men with prostate cancer: a systematic review of prevalence studies. Prostate Cancer Prostatic Dis 14: 1-13.

10. Xiao H, Tan F, Goovaerts P, Ali A, Adunlin G, et al. (2013) Construction of a comorbidity index for prostate cancer patients linking state cancer registry with inpatient and outpatient data. J Registry Manag 40: 159-164.

11. Navarro VJ, Khan I, Bjornsson E, Seeff LB, Serrano J, et al. (2017) Liver injury from herbal and dietary supplements. Hepatology 65: 363-373.

12. Mazzanti G, Menniti-Ippolito F, Moro PA, Cassetti F, Raschetti R, et al. (2009) Hepatotoxicity from green tea: A review of the literature and two unpublished cases. Eur $\mathrm{J}$ Clin Pharmacol 65: 331-341.

13. Paschos A, Pandya R, Duivenvoorden WC, Pinthus JH (2013) Oxidative stress in prostate cancer: Changing research concepts towards a novel paradigm for prevention and therapeutics. Prostate Cancer Prostatic Dis 16: 217-225.

14. Adhami VM, Ahmad N, Mukhtar H (2003) Molecular targets for green tea in prostate cancer prevention. J Nutr 133: 2417S-2424S.

15. Yu F, Jin Z, Jiang H, Xiang C, Tang J, et al. (2014) Tea consumption and the risk of five major cancers: A dose-response meta-analysis of prospective studies. BMC Cancer 14: 197.

16. Kumar NB, Pow-Sang J, Egan KM, Spiess PE, Dickinson S, et al. (2015) Randomized, placebo-controlled trial of green tea catechins for prostate cancer prevention. Cancer Prev Res (Phila) 8: 879-887.

17. Jatoi A, Ellison N, Burch PA, Sloan JA, Dakhil SR, et al. (2003) A phase II trial of green tea in the treatment of patients with androgen independent metastatic prostate carcinoma. Cancer 97: 1442-1446.

18. Guess BW, Scholz MC, Strum SB, Lam RY, Johnson HJ, et al. (2003) Modified citrus pectin (MCP) increases the prostate-specific antigen doubling time in men with prostate cancer: A phase II pilot study. Prostate Cancer Prostatic Dis 6: $301-304$.

19. Yan J, Katz A (2010) PectaSol-C modified citrus pectin induces apoptosis and inhibition of proliferation in human and 
mouse androgen-dependent and- independent prostate cancer cells. Integr Cancer Ther 9: 197-203.

20. Pienta KJ, Naik H, Akhtar A, Yamazaki K, Replogle TS, et al. (1995) Inhibition of spontaneous metastasis in a rat prostate cancer model by oral administration of modified citrus pectin. J Natl Cancer Inst 87: 348-353.

21. Leclere L, Fransolet $M$, Cambier $P$, El Bkassiny $S$, Tikad A, et al. (2016) Identification of a cytotoxic molecule in heat-modified citrus pectin. Carbohydr Polym 137: 39-51.

22. Jiang J, Eliaz I, Sliva D (2013) Synergistic and additive effects of modified citrus pectin with two polybotanical compounds, in the suppression of invasive behavior of human breast and prostate cancer cells. Integr Cancer Ther 12: 145-152.

23. Glinsky VV, Raz A (2009) Modified citrus pectin anti-metastatic properties: One bullet, multiple targets. Carbohydr Res 344: 1788-1791.

24. Azemar M, Hildenbrand B, Haering B, Heim M, Unger C (2007) Clinical benefit in patients with advanced solid tumors treated with modified citrus pectin: A prospective pilot study. Clinical Medicine Insights: Oncology 1: 73-80.

25. Vlachojannis C, Zimmermann BF, Chrubasik-Hausmann $S$ (2015) Efficacy and safety of pomegranate medicinal products for cancer. Evid Based Complement Alternat Med 2015: 258598.

26. Adhami VM, Siddiqui IA, Syed DN, Lall RK, Mukhtar H (2012) Oral infusion of pomegranate fruit extract inhibits prostate carcinogenesis in the TRAMP model. Carcinogenesis 33: 644-651.

27. Pantuck AJ, Leppert JT, Zomorodian N, Aronson W, Hong J, et al. (2006) Phase II study of pomegranate juice for men with rising prostate-specific antigen following surgery or radiation for prostate cancer. Clin Cancer Res 12: 4018-4026.

28. Rettig MB, Heber D, An J, Seeram NP, Rao JY, et al. (2008) Pomegranate extract inhibits androgen-independent prostate cancer growth through a nuclear factor-kappaB-dependent mechanism. Mol Cancer Ther 7: 2662-2671.

29. Hong MY, Seeram NP, Heber D (2008) Pomegranate polyphenols down-regulate expression of androgen-synthesizing genes in human prostate cancer cells overexpressing the androgen receptor. J Nutr Biochem 19: 848-855.

30. Paller CJ, Ye X, Wozniak PJ, Gillespie BK, Sieber PR, et al. (2013) A randomized phase II study of pomegranate extract for men with rising PSA following initial therapy for localized prostate cancer. Prostate Cancer Prostatic Dis 16: 50-55.

31. Freedland SJ, Carducci M, Kroeger N, Partin A, Rao JY, et al. (2013) A double-blind, randomized, neoadjuvant study of the tissue effects of $\mathrm{POMx}$ pills in men with prostate cancer before radical prostatectomy. Cancer Prev Res (Phila) 6: 1120-1127.

32. Stenner-Liewen F, Liewen $\mathrm{H}$, Cathomas R, Renner C, Petrausch $U$, et al. (2013) Daily pomegranate intake has no impact on PSA levels in patients with advanced prostate cancer - Results of a phase Ilb randomized controlled trial. J Cancer 4: 597-605.

33. Tabassum A, Bristow RG, Venkateswaran V (2010) Ingestion of selenium and other antioxidants during prostate cancer radiotherapy: A good thing? Cancer Treat Rev 36: 230-234.

34. Cai X, Wang C, Yu W, Fan W, Wang S, et al. (2016) Selenium Exposure and Cancer Risk: An Updated Meta-analysis and Meta-regression. Sci Rep 6: 19213.

35. Menter DG, Sabichi AL, Lippman SM (2000) Selenium effects on prostate cell growth. Cancer Epidemiol Biomarkers Prev 9: 1171-1182.
36. Cui Z, Liu D, Liu C, Liu G (2017) Serum selenium levels and prostate cancer risk: A MOOSE-compliant meta-analysis. Medicine (Baltimore) 96: e5944.

37. Vinceti M, Dennert G, Crespi CM, Zwahlen M, Brinkman $M$, et al. (2014) Selenium for preventing cancer. Cochrane Database Syst Rev 1: CD005195.

38. Lu J, Zhang J, Jiang C, Deng Y, Ozten N, et al. (2016) Cancer chemoprevention research with selenium in the post-SELECT era: Promises and challenges. Nutr Cancer 68: 1-17.

39. Lippman SM, Klein EA, Goodman PJ, Lucia MS, Thompson IM, et al. (2009) Effect of selenium and vitamin E on risk of prostate cancer and other cancers: The selenium and vitamin E cancer prevention trial (SELECT). JAMA 301: 39-51.

40. Kristal AR, Darke AK, Morris JS, Tangen CM, Goodman PJ, et al. (2014) Baseline selenium status and effects of selenium and vitamin e supplementation on prostate cancer risk. J Natl Cancer Inst 106: djt456.

41. Galli F, Azzi A, Birringer M, Cook-Mills JM, Eggersdorfer M, et al. (2017) Vitamin E: Emerging aspects and new directions. Free Radic Biol Med 102: 16-36.

42. Ramamoorthy V, Rubens M, Saxena A, Shehadeh N (2015) Selenium and vitamin E for prostate cancer--justifications for the SELECT study. Asian Pac J Cancer Prev 16: 2619-2627.

43. Das Gupta S, Suh N (2016) Tocopherols in cancer: An update. Mol Nutr Food Res 60: 1354-1363.

44. Jiang Q, Wong J, Fyrst H, Saba JD, Ames BN (2004) Gamma-Tocopherol or combinations of vitamin $E$ forms induce cell death in human prostate cancer cells by interrupting sphingolipid synthesis. Proc Natl Acad Sci U S A 101: 17825-17830.

45. Heinonen OP, Albanes D, Virtamo J, Taylor PR, Huttunen JK, et al. (1998) Prostate cancer and supplementation with alpha-tocopherol and beta-carotene: Incidence and mortality in a controlled trial. J Natl Cancer Inst 90: 440-446.

46. Bjelakovic G, Nikolova D, Gluud LL, Simonetti RG, Gluud C (2007) Mortality in randomized trials of antioxidant supplements for primary and secondary prevention: Systematic review and meta-analysis. JAMA 297: 842-857.

47. Chen J, O'Donoghue A, Deng YF, Zhang B, Kent F, et al. (2014) The effect of lycopene on the PI3K/Akt signalling pathway in prostate cancer. Anticancer Agents Med Chem 14: 800-805

48. Goo YA, Li Z, Pajkovic N, Shaffer S, Taylor G, et al. (2007) Systematic investigation of lycopene effects in LNCaP cells by use of novel large-scale proteomic analysis software. Proteomics Clin Appl 1: 513-523.

49. Wang Y, Cui R, Xiao Y, Fang J, Xu Q (2015) Effect of carotene and lycopene on the risk of prostate cancer: A systematic review and dose-response meta-analysis of observational studies. PLoS One 10: e0137427.

50. Peters U, Leitzmann MF, Chatterjee N, Wang Y, Albanes D, et al. (2007) Serum lycopene, other carotenoids, and prostate cancer risk: A nested case-control study in the prostate, lung, colorectal, and ovarian cancer screening trial. Cancer Epidemiol Biomarkers Prev 16: 962-968.

51. Gann PH, Ma J, Giovannucci E, Willett W, Sacks FM, et al. (1999) Lower prostate cancer risk in men with elevated plasma lycopene levels: Results of a prospective analysis. Cancer Res 59: 1225-1230.

52. Grainger EM, Schwartz SJ, Wang S, Unlu NZ, Boileau TW, et al. (2008) A combination of tomato and soy products for men with recurring prostate cancer and rising prostate specific antigen. Nutr Cancer 60: 145-154. 
53. Clark PE, Hall MC, Borden LS Jr, Miller AA, Hu JJ, et al (2006) Phase I-II prospective dose-escalating trial of lycopene in patients with biochemical relapse of prostate cancer after definitive local therapy. Urology 67: 1257-1261.

54. Vaishampayan U, Hussain M, Banerjee M, Seren S, Sarkar $\mathrm{FH}$, et al. (2007) Lycopene and soy isoflavones in the treatment of prostate cancer. Nutr Cancer 59: 1-7.

55. Hwang YW, Kim SY, Jee SH, Kim YN, Nam CM (2009) Soy food consumption and risk of prostate cancer: A meta-analysis of observational studies. Nutr Cancer 61: 598-606.

56. Burich RA, Holland WS, Vinall RL, Tepper C, White RW, et al. (2008) Genistein combined polysaccharide enhances activity of docetaxel, bicalutamide and Src kinase inhibition in androgen-dependent and independent prostate cancer cell lines. BJU Int 102: 1458-1466.

57. Tepper CG, Vinall RL, Wee CB, Xue L, Shi XB, et al. (2007) GCP-mediated growth inhibition and apoptosis of prostate cancer cells via androgen receptor-dependent and -independent mechanisms. Prostate 67: 521-535.

58. Vinall RL, Hwa K, Ghosh P, Pan CX, Lara PN, et al. (2007) Combination treatment of prostate cancer cell lines with bioactive soy isoflavones and perifosine causes increased growth arrest and/or apoptosis. Clin Cancer Res 13: 62046216.

59. Huang X, Chen S, Xu L, Liu Y, Deb DK, et al. (2005) Genistein inhibits p38 map kinase activation, matrix metalloproteinase type 2, and cell invasion in human prostate epithelial cells. Cancer Res 65: 3470-3478.

60. Ahmad A, Biersack B, Li Y, Bao B, Kong D, et al. (2013) Perspectives on the role of isoflavones in prostate cancer. AAPS J 15: 991-1000.

61. Wang Y, Raffoul JJ, Che M, Doerge DR, Joiner MC, et al. (2006) Prostate cancer treatment is enhanced by genistein in vitro and in vivo in a syngeneic orthotopic tumor model. Radiat Res 166: 73-80.

62. Wang J, Eltoum IE, Lamartiniere CA (2004) Genistein alters growth factor signaling in transgenic prostate model (TRAMP). Mol Cell Endocrinol 219: 171-180.

63. Mentor-Marcel R, Lamartiniere CA, Eltoum IA, Greenberg NM, Elgavish A (2005) Dietary genistein improves survival and reduces expression of osteopontin in the prostate of transgenic mice with prostatic adenocarcinoma (TRAMP). J Nutr 135: 989-995.

64. Naik HR, Lehr JE, Pienta KJ (1994) An in vitro and in vivo study of antitumor effects of genistein on hormone refractory prostate cancer. Anticancer Res 14: 2617-2619.

65. Nelles JL, Hu WY, Prins GS (2011) Estrogen action and prostate cancer. Expert Rev Endocrinol Metab 6: 437-451.

66. Van Die MD, Bone KM, Williams SG, Pirotta MV (2014) Soy and soy isoflavones in prostate cancer: A systematic review and meta-analysis of randomized controlled trials. BJU Int 113: 119-130.

67. DeVere White RW, Tsodikov A, Stapp EC, Soares SE, Fujii $H$, et al. (2010) Effects of a high dose, aglycone-rich soy extract on prostate-specific antigen and serum isoflavone concentrations in men with localized prostate cancer. Nutr Cancer 62: 1036-1043.

68. Kumar NB, Krischer JP, Allen K, Riccardi D, Besterman-Dahan $\mathrm{K}$, et al. (2007) A Phase II randomized, placebo-controlled clinical trial of purified isoflavones in modulating steroid hormones in men diagnosed with localized prostate cancer. Nutr Cancer 59: 163-168.
69. Kumar NB, Kang L, Pow-Sang J, Xu P, Allen K, et al. (2010) Results of a randomized phase I dose-finding trial of several doses of isoflavones in men with localized prostate cancer: Administration prior to radical prostatectomy. J Soc Integr Oncol 8: 3-13.

70. Lazarevic B, Boezelijn G, Diep LM, Kvernrod K, Ogren O, et al. (2011) Efficacy and safety of short-term genistein intervention in patients with localized prostate cancer prior to radical prostatectomy: A randomized, placebo-controlled, double-blind Phase 2 clinical trial. Nutr Cancer 63: 889-898.

71. Miyanaga N, Akaza H, Hinotsu S, Fujioka T, Naito S, et al. (2012) Prostate cancer chemoprevention study: An investigative randomized control study using purified isoflavones in men with rising prostate-specific antigen. Cancer Sci 103: 125-130.

72. Dalais FS, Meliala A, Wattanapenpaiboon N, Frydenberg M, Suter DA, et al. (2004) Effects of a diet rich in phytoestrogens on prostate-specific antigen and sex hormones in men diagnosed with prostate cancer. Urology 64: 510-515.

73. Hamilton-Reeves JM, Rebello SA, Thomas W, Slaton JW, Kurzer MS (2007) Isoflavone-rich soy protein isolate suppresses androgen receptor expression without altering estrogen receptor-beta expression or serum hormonal profiles in men at high risk of prostate cancer. J Nutr 137: 1769-1775.

74. Kumar NB, Cantor A, Allen K, Riccardi D, Besterman-Dahan $\mathrm{K}$, et al. (2004) The specific role of isoflavones in reducing prostate cancer risk. Prostate 59: 141-147.

75. Abdel Bar FM (2015) New chalcanonol glycoside from the seeds of saw palmetto: Antiproliferative and antioxidant effects. Nat Prod Res 29: 926-932.

76. Scholtysek C, Krukiewicz AA, Alonso JL, Sharma KP, Sharma PC, et al. (2009) Characterizing components of the Saw Palmetto Berry Extract (SPBE) on prostate cancer cell growth and traction. Biochem Biophys Res Commun 379: 795-798.

77. Bonnar-Pizzorno RM, Littman AJ, Kestin M, White E (2006) Saw palmetto supplement use and prostate cancer risk. Nutr Cancer 55: 21-27.

78. Andriole GL, McCullum-Hill C, Sandhu GS, Crawford ED, Barry MJ, et al. (2013) The effect of increasing doses of saw palmetto fruit extract on serum prostate specific antigen: analysis of the CAMUS randomized trial. J Urol 189: 486-492.

79. Avins AL, Lee JY, Meyers CM, Barry MJ, Group CS (2013) Safety and toxicity of saw palmetto in the CAMUS trial. J Urol 189: 1415-1420.

80. Hsu JW, Yasmin-Karim S, King MR, Wojciechowski JC, Mickelsen D, et al. (2011) Suppression of prostate cancer cell rolling and adhesion to endothelium by 1alpha,25-dihydroxyvitamin D3. Am J Pathol 178: 872-880.

81. Gregory KJ, Zhao B, Bielenberg DR, Dridi S, Wu J, et al. (2010) Vitamin D binding protein-macrophage activating factor directly inhibits proliferation, migration, and UPAR expression of prostate cancer cells. PLoS One 5: e13428.

82. Mordan-McCombs S, Brown T, Wang WL, Gaupel AC, Welsh J, et al. (2010) Tumor progression in the LPB-Tag transgenic model of prostate cancer is altered by vitamin D receptor and serum testosterone status. J Steroid Biochem Mol Biol 121: 368-371.

83. Zheng $Y$, Zhou H, Ooi LL, Snir AD, Dunstan CR, et al. (2011) Vitamin D deficiency promotes prostate cancer growth in bone. Prostate 71: 1012-1021. 
84. Cardoso AT, Nanji L, Costa J, Vaz-Carneiro A (2014) Analysis of the cochrane review: Vitamin $D$ supplementation for prevention of cancer in adults. Cochrane Database Syst Rev. 2014, 6:CD007469. Acta Med Port 27: 411-413.

85. Srinivas S, Feldman D (2009) A phase II trial of calcitriol and naproxen in recurrent prostate cancer. Anticancer Res 29: 3605-3610.

86. Chadha MK, Tian L, Mashtare T, Payne V, Silliman C, et al (2010) Phase 2 trial of weekly intravenous 1,25 dihydroxy cholecalciferol (calcitriol) in combination with dexamethasone for castration-resistant prostate cancer. Cancer 116 : 2132-2139.

87. Samson K (2015) Evidence that vitamin D can slow or reverse low-grade prostate cancer. Oncology Times 37: 55-56.

88. Marshall DT, Savage SJ, Garrett-Mayer E, Keane TE, Hollis BW, et al. (2012) Vitamin D3 supplementation at 4000 international units per day for one year results in a decrease of positive cores at repeat biopsy in subjects with low-risk prostate cancer under active surveillance. J Clin Endocrinol Metab 97: 2315-2324.
89. Sule K, Szentmihalyi K, Szabo G, Kleiner D, Varga I, et al. (2018) Metal- and redox homeostasis in prostate cancer with vitamin $D_{3}$ supplementation. Biomed Pharmacother 105: 558-565.

90. Matusheski NV, Juvik JA, Jeffery EH (2004) Heating decreases epithiospecifier protein activity and increases sulforaphane formation in broccoli. Phytochemistry 65: 1273-1281.

91. Traka MH, Melchini A, Mithen RF (2014) Sulforaphane and prostate cancer interception. Drug Discov Today 19: 1488-1492.

92. Liu B, Mao Q, Cao M, Xie L (2012) Cruciferous vegetables intake and risk of prostate cancer: a meta-analysis. Int $\mathrm{J}$ Urol 19: 134-141.

93. Alumkal JJ, Slottke R, Schwartzman J, Cherala G, Munar $M$, et al. (2015) A phase II study of sulforaphane-rich broccoli sprout extracts in men with recurrent prostate cancer. Invest New Drugs 33: 480-489.

94. Cipolla BG, Mandron E, Lefort JM, Coadou Y, Della Negra E, e al. (2015) Effect of Sulforaphane in Men with Biochemical Recurrence after Radical Prostatectomy. Cancer Prev Res (Phila) 8: 712-719. 